\title{
BIOLOGIC THERAPY FOR PSORIASIS PATIENTS
}

\section{TERAPI BIOLOGIK PADA PASIEN PSORIASIS}

\author{
M. Athuf Thaha \\ Sub Bagian Alergi/ Imunologi Departemen IImu Kesehatan Kulit \& Kelamin FK UNSRI/ RS dr. M. Hoesin \\ Palembang
}

\begin{abstract}
Treatment limitations of current immunosuppressive therapies, and growing understanding of psoriasis pathogenesis on a molecular level have stimulated much interest in the field of immunomodulatory therapy for management of psoriasis. Genetic engineering has allowed the development of proteins that are targeted to specific cell surface receptors. A well over 40 targeted biologic agents are in preclinical and clinical testing for $T$-cell mediated inflammatory diseases, including psoriasis. It is important that, as a doctor become well educated in biologics, since several of these agents are available for the management of psoriasis.
\end{abstract}

Keywords: immunosuppressive therapy, immunomodulatory therapy, genetic engineering, surface receptors, targeted biologic agents, biologics.

\section{PENDAHULUAN}

Dalam kurun waktu 10-20 tahun belakangan ini patogenesis psoriasis telah berubah drastis, hiperproliferasi dan diferensiasi abnormal epidermis merupakan proses sekunder akibat aktivasi sistem imun dalam lesi kulit yang diperantarai oleh sel Th1 dan Tc1 (CD4+CD45RO+ dan CD8+CD45RO+). Dengan demikian psoriasis merupakan " $T$-cell mediated inflammatory disease" (1). Bukti nyata dari peran sentral sel Th1 dan Tc1 dalam patogenesis psoriasis ditunjukkan dari hasil penelitian DAB389 IL2 (bersifat toksis terhadap sel-sel yang mengekspresikan IL-2R, dalam hal ini sel-sel yang paling utama mengekspresikan IL-2R ialah sel Th1 dan Tc1).

Obat-obat metotreksat, siklosporin, kalsitriol, UVB dan PUVA menunjukkan efektifitas pada psoriasis; tetapi karena sifat imunosupresi global nya sehingga menyebabkan efek toksis tidak hanya terhadap sel-sel sistem imun tetapi juga terhadap selsel di luar sistem imun.

Karena kendala tersebut, disamping pemahaman patogenesis baru serta bantuan teknik rekayasa genetik, dikembangkan strategi pengobatan dengan target spesifik, menggunakan protein (hasil rekayasa genetik) yang dikenal dengan Biologic therapy atau Biologics. Diharapkan bahan tersebut lebih efektif, memberikan remisi panjang, selektif dan tidak toksis secara sistemik sehingga aman digunakan untuk pengobatan jangka panjang ("Selective Immuno Modulating Agents"SIMA) (2). Artikel ini bertujuan menjelaskan mengenai berbagai agen terapi biologik sebagai terapi baru pada pasien psoriasis. Karena penggunaan biologics sangat erat

Jurnal Kedokteran Brawijaya, Vol. XXIV, No. 3, Desember 2008 Korespondensi: M. Athuf Thaha, Sub Bagian Alergi/ Imunologi Departemen IImu Kesehatan Kulit \& Kelamin FK UNSRI/ RS dr. M. Hoesin Palembang. Telepon:0771316671 kaitannya dengan proses respon imun, agar pemahamannya dapat lebih mudah, akan dibahas terlebih dahulu secara singkat mengenai rangkaian aktivasi seluler sehingga terjadi reaksi imun melalui perantaraan sel $\mathrm{T}$.

\section{RESPON IMUN}

Pada keadaan normal (tidak ada stimulasi antigenik), sel penyaji antigen (antigen presenting cells/APC) berada dalam keadaan imatur dan sel sel limfosit $\mathrm{T}$ masih dalam bentuk naive (naive $\mathrm{T}$ cell/ sel T CD4+CD45+RA+). Apabila ada stimulasi antigenik, sel penyaji akan menangkap/ menelan dan memproses antigen menjadi peptida antigenik serta mempresentasikannya kepermukaan sel bersama Major Histocompatibity Complex/MHC I/ II. Sel penyaji antigen sekarang mengalami pematangan (mature), ditandai dengan berbagai ekspresi molekul permukaan (ICAM-1, LFA-3, CD80, CD86, CD40) dan bermigrasi menuju kelenjar getah bening regional melalui aliran getah bening aferen, dan siap untuk mengaktifkan sel $T$ naive. Pertemuan dan interaksi antara sel APC matur dengan sel $\mathrm{T}$ naive didalam kelenjar, diawali dengan penggandengan molekul ICAM-1 dengan bagian ekstraselular molekul LFA-1 ( CD11a). Kejadian berikut adalah interaksi antara molekul pengenal antigen sel T ( TCR/CD3) dengan peptida antigenik, dan antara molekul CD4/CD8 pada sel T dengan MHC I/ II. Pada saat tersebut, bila ada kecocokan antara pasangan molekul tersebut, sel T naive mengalami aktivasi tetapi belum optimal. Agar aktivasi sel $\mathrm{T}$ optimal, diperlukan interaksi molekul tambahan (accessory/ costimulatory signals) yaitu LFA-3, CD80/CD86, CD40 pada sel penyaji yang masing-masing akan berinteraksi dengan CD2, CD28/CTLA-4, dan CD40L pada permukaan sel T naive. Sekarang sel $\mathrm{T}$ naive menjadi aktif (sel Th1 $\mathrm{CD} 4+\mathrm{CD} 45+\mathrm{RO}+)$ dan mensekresikan IL-2 serta 
mengekspresikan IL-2R (CD25) pada permukaannya, dan sel APC mensekresikan IL-12. Selain itu dengan adanya interaksi antara CD40 dengan CD40L, memungkinkan sel APC menstimulasi diferensiasi sel Tc1 (sel Tc1 CD8+CD45+RO+). Interaksi antara IL-2 dengan IL-2R dan IL-12 dengan reseptornya (IL-12R) menyebabkan sel berproliferasi dan berdiferensiasi menjadi sel T CD4+CD45+RO+ efektor dan memory, dan mensekresikan IFN- $\gamma$, GM-CSF serta meng upgrade molekul CLA (cutaneous leucocyte antigen/ skin homing antigen), VLA-4 (very late antigen-4), dan lebih banyak LFA-1 pada permukaannya (sel Th dan sel Tc). Molekul-molekul tersebut diperlukan sel T aktif untuk bermigrasi ke lokasi peradangan melalui endotel pembuluh darah. Di dalam lokasi peradangan, sel Th1 dan sel Tc1 akan mengalami reaktivasi (akibat interaksi dengan antigen), dan melepaskan IFN- $\gamma$, TNF- $\alpha$, GM-CSF di dalam lokasi radang. IFN- $\gamma$ akan memicu sel keratinosit melepaskan IL-8 dan sel makrofag mensekresikan lebih banyak TNF- $\alpha$. Oleh pengaruh kemokin IL-8, sel radang PMN dikerahkan ke dalam lokasi peradangan. Kesemuanya, khusus pada kasus psoriasis akan menghasilkan kelainan klinik sebagai akibat dari terjadinya hiperproliferasi keratinosit dan angiogenesis. Dari uraian di atas, dapat disimpulkan bahwa yang berperan sentral dalam terjadinya penyakit adalah sel Th1 dan Tc1 patogenik (CD4+CD45+RO+ dan CD8+CD45+RO+), dan sel tersebut merupakan target spesifik bagi terapi biologik $(1,3)$.

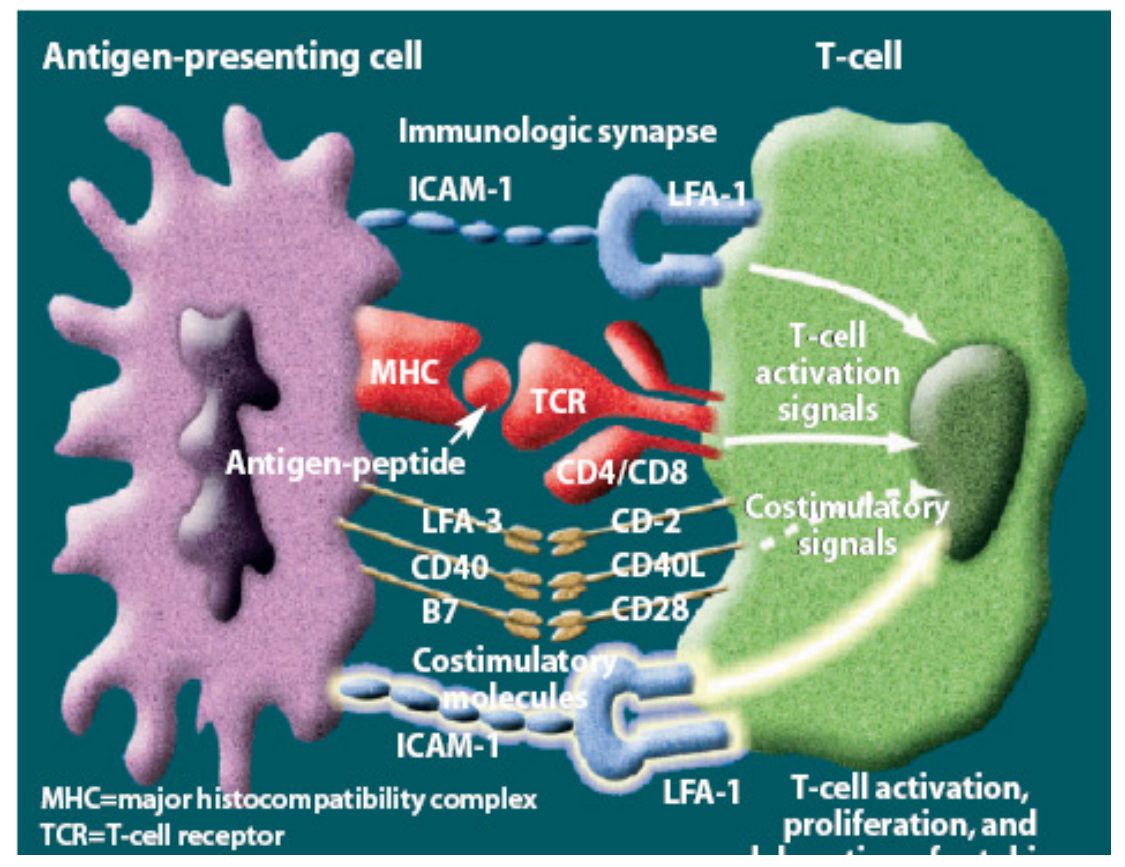

Gambar 1. Stimulasi sel T naive oleh sel sel APC matur dalam kelenjar getah bening regional. (dikutip dari Pariser (4).

\section{TERAPI BIOLOGIK / BIOLOGICS}

Terapi biologik / Biologics ialah protein yang memiliki aktivitas farmakologik, yang berasal dari material hidup, baik dari manusia, hewan, atau mikroorganisme, dan dapat disintesis dalam jumlah besar dengan bantuan teknik rekayasa genetik (recombinant DNA techniques).

Tiga tipe bahan biologik $(1,4)$ :

1. Antibodi monoklonal: mengikat protein pada permukaan sel dan mengubah aktivitas protein target tersebut.

a. Humanized: terbanyak digunakan, sejumlah asam amino bagian Fc imunoglobulin manusia diganti dengan sekuens pengikat spesifik yang berasal dari antibodi monoklonal murine. Karena kesamaan dengan protein manusia normal/ karena rancangannya paling fleksibel, resiko timbul respon imun terhadap bagian murine nya kecil. Nama bahan golongan ini di beri kode dengan akhiran: zumab.

b. Primatized: sekuens monyet dalam human backbone.

c. Fully human: dikode dengan akhiran: umab.

d. Chimeric: penggabungan segmen manusia dengan mouse, dikode dengan akhiran: ximab.

2. Sitokin atau faktor pertumbuhan (growth factors) manusia hasil rekayasa (recombinant human cytokines): molekul merupakan replika atau fragmen dari protein manusia normal. Bahan menghasilkan efek dengan cara berinteraksi dengan reseptor seluler normal.

3. Protein gabungan (fusion proteins): menggabungkan peptida atau bagian dari protein manusia dengan toksin; atau berupa konstruksi fully human antara bagian konstan (Fc) molekul 
imunoglobulin dengan binding site suatu reseptor. Bahan jenis ini dikode dengan akhiran: cept.

Terapi biologik adalah protein yang dirancang untuk mengikat target-target ekstraseluler (extracellular adhesion protein, reseptor, sitokin, dan kemokin), dengan tujuan memblok aktivasi molekuler yang terjadi, sehingga dapat mencegah timbulnya reaksi imun yang diperantarai sel $T$ dan/ sel $B$. Secara garis besar, tujuan penggunaan terapi biologik adalah (1):

1. Mentarget sel T patogenik,

2. Memblok aktivasi dan/migrasi sel $\mathrm{T}$,
3. Menginduksi deviasi imun (induce immune deviation),

4. Memblok kerja sitokin.

Sampai saat ini, Food and Drug Administration (FDA) telah menyetujui penggunaan alefacept, efalizumab, dan etanercept untuk pengobatan psoriasis moderate-to-severe, sedang infliximab dan adalimumab masih dalam tahap penelitian (4).

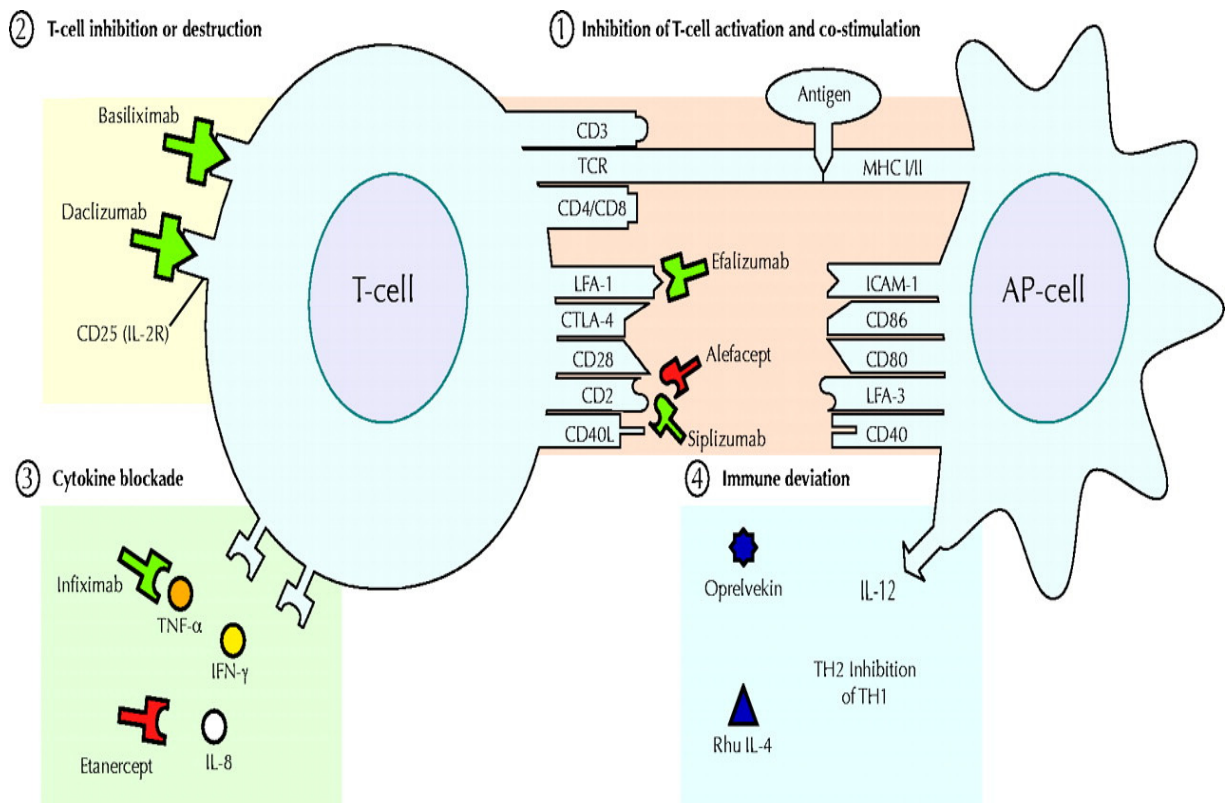

Gambar 2. Agen biologik dan target yang dituju (1). Berbagai efek agen biologik terhadap target spesifik pada permukaan sel APC dan sel T, dan target yang beredar dalam sirkulasi

\section{Alefacept (Amevive)}

LFA-3lg fusion protein; LFA-3 tip : karena hanya mengandung domain eksternal LFA-3. Pabrik pembuat : Biogen, Inc, Cambridge, Mass. Bagian LFA-3 ( tip dari alefacept) mengikat CD2 pada permukaan sel T aktif, dan bagian Fc IgG1 ( tail dari alefacept) diikat oleh sel NK melalui FcyRIII (CD16). Akibatnya CD2 sel T tidak dapat berinteraksi dengan LFA-3 sel APC, sehingga aktivasi sel T terhambat, dan sel NK yang mengikat bagian tail dari alefacept, menggunakan ikatan tersebut sebagai jembatan untuk menyebabkan apoptosis sel $\mathrm{T}$ melalui mekanisme pelepasan granzyme. Ini berarti alefacept tidak hanya menyebabkan terganggunya aktivasi sel $\mathrm{T}$, tetapi juga menyebabkan kematian sel T memory patogenik (sel Th1 dan sel Tc1 aktif) (5).

Alefacept telah disetujui penggunaannya oleh FDA pada pasien dewasa dengan moderate-to-severe psoriasis pada Januari 2003.

Kontraindikasi alefacept.

1. Sedang mendapat terapi imunosupresif lain atau phototherapy,
2. Status HIV positif,

3. Sel limfosit T CD4+ : $<250 \mathrm{sel} / \mu \mathrm{L}$,

4. Riwayat infeksi berulang, sedang menderita infeksi kronis, atau tes tuberkulin +,

5. Riwayat keganasan sistemik dalam 5 tahun terakhir,

6. Ibu hamil atau menyusui.

Setelah 12 minggu $15 \mathrm{mg} / \mathrm{ming} g \mathrm{u}$, intramuscular (i.m.) persentase pasien yang mencapai PASI 75 pada minggu 14 adalah 21\% (pasebo 5\%). Terjadi penurunan sel $\mathrm{CD} 4^{+}$and $\mathrm{CD} 8^{+}$, dan perbaikan klinis berkorelasi dengan penurunan sel dalam kulit (bukan dengan sel dalam sirkulasi). Terapi dapat dilanjutkan 12 minggu berikut, asalkan jumlah sel CD4+ dan CD8+ dalam batas normal (keberhasilan setelah 24 minggu: 44\%). Remisi tanpa pengobatan adalah 209 hari. Insiden efek samping alefacept $2 \%$, lebih tinggi dibandingkan placebo, berupa faringitis, dizziness, increased cough, mual, pruritus, mialgia, chills, injection-site pain, injection-site inflammation, 
dan accidental injury. Sediaan intravenous (i.v.) tidak tersedia untuk penggunaan klinis.

Walau terjadi penurunan sel $\mathrm{T} \mathrm{CD} 4^{+}$dan $\mathrm{CD} 8^{+}$, tetapi tidak mempengaruhi fungsi imun ( sel NK dan sel B yang juga mengekspresikan CD2 tidak terganggu, demikian pula sel $T$ naive). Resiko infeksi sedikit meningkat, dan rerata infeksi serius yang memerlukan perawatan rumah sakit sebesar: 0.9\% Efalizumab
(Raptiva) (placebo: 0.2\%). Insiden infeksi tampaknya tidak berkaitan dengan penurunan sel T CD4+. Tidak ditemui peningkatan resiko tuberkulosis (TB), gangguan syaraf pusat (CNS), atau gagal jantung.

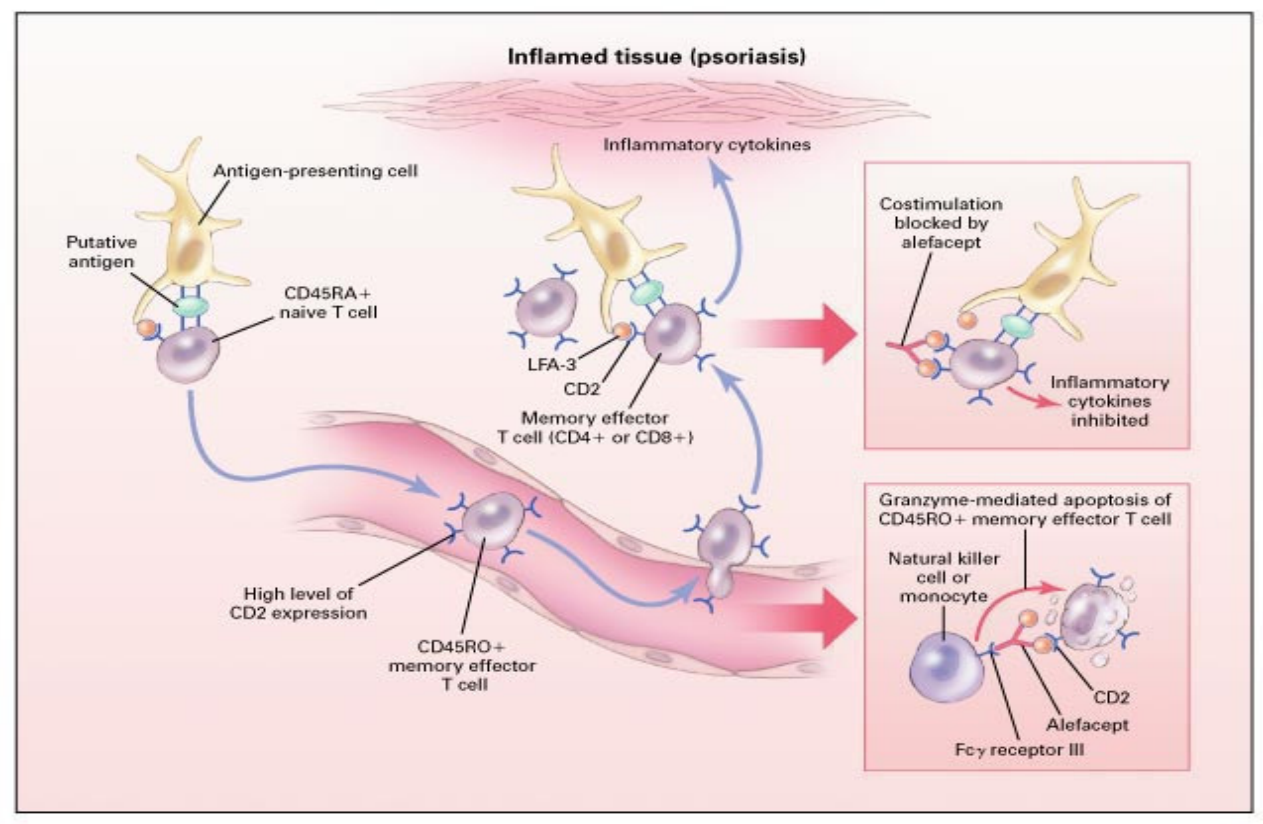

Gambar 3. Mekanisme kerja alefacept (5)

Humanized monoclonal antibody anti CD11a. Sebelumnya dikenal sebagai Hu1124. Pembuat : Genentech, Inc, South San Fransisco, Calif, dan Xoma, Inc, Berkeley, Calif. LFA-1 adalah integrin (pada permukaan sel T), merupakan molekul heterodimer yang tersusun dari rantai- $\alpha$ (CD11a) dan rantai- $\beta$ (CD18). Efalizumab memblok secara reversibel bagian eksternal CD11a sehingga LFA-1 tidak dapat berinteraksi dengan ICAM-1 pada sel APC, endotel, dan sel keratinosit. Akibatnya, aktivasi awal, adesi, migrasi melalui endotel, dan interaksi dengan sel keratinosit dalam lesi terhambat. Indikasi pemberian : pencegahan penolakan organ alograf, dan psoriasis. Efalizumab tidak menyebabkan kematian sel T (disease suppressive SIMA).

Dosis: $1 \mathrm{mg} / \mathrm{kg} / \mathrm{minggu}$, subcutaneous (s.c.) selama 3 bulan, dapat dilanjutkan 3 bulan berikutnya sebagai terapi pemeliharaan dengan dosis sama. Perbaikan setelah 3 bulan 27\%, dan setelah 6 bulan $44 \%$.

Efek samping terbanyak berupa gejala mildto-moderate flu-like (headache, chills, fever, nausea) timbul pada dosis pertama atau kedua. Insiden keganasan rendah dan sama dengan placebo. Dapat terjadi trombositopenia reversibel $(0.3 \%)$, dapat pulih dengan pemberian steroid sistemik. Beberapa kasus psoriasis merupakan non-responders, sehingga diperlukan terapi alternatif. Masa remisi pasca terapi : 64-70 hari (6).

Efalizumab telah disetujui oleh FDA pada psoriasis plakat tipe moderat to severe pada Oktober 2003, tetapi terhitung Juni 2009 dilarang pemakaiannya di Amerika Serikat oleh FDA karena adanya 3 laporan kematian pasien yang mengalami progressive multifocal leukoencephalopathy (PML) akibat infeksi virus John Cunningham pada syaraf pusat (7).

\section{Infliximab ( Remicade, Centocor, Inc, Malvern, Pa )}

Chimeric (30\% murine, $70 \%$ human $)$ monoclonal antibody yang mengikat TNF- $\alpha$ bebas dan transmembrane-bound. Infliximab memblok interaksi TNF bebas pada reseptornya dan dapat mengaktifkan komplemen, dan menyebabkan lisis sel bila mengikat TNF yang terdapat pada permukaan sel. Infliximab telah disetujui penggunaannya pada rheumatoid arthritis dan Crohn's disease, tetapi belum disetujui pada psoriasis dan psoriatic arthritis. Terapi dilakukan di klinik, secara i.v. selama 2-4 jam, pada minggu 0, 2, dan 6. Dosis : $5 \mathrm{mg} / \mathrm{kg}$.

Setelah injeksi ke tiga, remisi yang terjadi cukup panjang. Pada pengobatan rheumatoid arthritis atau Crohn's disease, dianjurkan pengobatan lanjutan setiap 8 minggu. Pada beberapa pasien nonpsoriasis, dapat terbentuk neutralizing antibodies 
terhadap infliximab, sehingga dosis dan frekuensi obat perlu ditingkatkan untuk mempertahankan efektivitas. Untuk menghindari terbentuknya antibodi tersebut, pemberian infliximab dikombinasi dengan methotrexate (MTX).

Efek samping tersering headache, pruritus, fatigue, dan mialgia (insiden sama seperti placebo). Reaksi infus terjadi pada/ sesudah 3 injeksi pertama (15.7\% dan $2 \%$ placebo). Reaksi infus dapat diatasi dengan melambatkan atau menghentikan infus, pemberian infus larutan salin dan obat sesuai kebutuhan. Untuk terapi penderita dengan riwayat reaksi infus, diberikan difenhidramin dan asetaminofen sebelum infus infliximab. Reaksi infus berkorelasi dengan terbentuknya neutralizing antibodies (8).

Etanercept (Enbrel)

Fusion protein (TNF-R-Ig fusion protein, Immunex, Inc, Seattle, Wash), mengikat TNF dan memblok interaksinya dengan TNF-R Etanercept telah disetujui penggunaannya pada psoriasis (Mei 2004), ankylosing spondylitis, rheumatoid arthritis dan juvenile rheumatoid arthritis, inflammatory bowel disease, dan psoriatic arthritis.

Dosis yang direkomendasikan pada psoriasis: $50 \mathrm{mg}$ s.c., $2 \mathrm{x} / \mathrm{minggu}$, selama $12 \mathrm{minggu}$, dilanjutkan dengan dosis pemeliharaan $50 \mathrm{mg} / \mathrm{minggu}$ untuk 12 minggu. Remisi setelah 24 minggu, dapat bertahan selama 85 hari. Pada kasus yang kambuh, pengobatan dapat diulang kembali dengan dosis semula.

Insiden efek samping terbanyak adalah injection-site reactions, headache, upper respiratory infections, dan injection-site ecchymosis (sama dengan placebo, kecuali untuk injection- site reactions) (9).

\section{Adalimumab (Humira)}

Fully human, high-affinity monoclonal antibody terhadap TNF-a bebas/ soluble dan yang terikat pada membran. Adalimumab menyebabkan lisis sel yang mengekspresikan TNF pada permukaannya dengan bantuan komplemen (in vitro). Adalimumab telah disetujui penggunaannya pada artritis reumatoid dan pada psoriasis. Pada psoriasis, dosis : $80 \mathrm{mg}$ s.c. pada minggu 1 dan 2, dilanjutkan dengan $40 \mathrm{mg}$ s.c. pada minggu 3 sampai 12 .

Indikasi adalimumab (dan alefacept).

1. Pada psoriasis plakat kronik moderate to severe, usia $\geq 18$ tahun yang memenuhi kriteria berikut:

- Penyakit tidak dapat dikontrol dengan terapi topikal

- Kegagalan phototherapy atau terapi sistemik lainnya mencapai respon klinik adekuat; atau terdapat kontraindikasi penggunaan phototherapy atau terapi sistemik lain (misal MTX)

- Memenuhi kriteria psoriasis plakat kronik moderate to severe (lesi plakat $>10 \%$ body surface area (BSA), atau lesi plakat $\leq 10 \%$ BSA tetapi mengenai area sensitif atau area yang secara signifikan mempengaruhi fungsi harian (telapak tangan, telapak kaki, kepala/leher, atau genitalia).

2. Pada artritis psoriatik moderate to severe, usia $\geq$ 18 tahun yang memenuhi kriteria berikut:

- Artritis aktif, minimal dengan pembengkakan 3 persendian dan nyeri 3 persendian

- Terdapat lesi plakat dengan diameter $\geq 2 \mathrm{~cm}$

- Artritis dengan distribusi:
a. mengenai persendian distal interphalangeal
b. artritis poliartikuler tanpa nodul rematoid
c. artritis mutilans
d. artritis asimetrik
e. artritis ankylosing spondylitis-like

- Kegagalan terapi disease-modifying antirheumatic drug (DMARD) mencapai respon klinik adekuat, atau terdapat kontraindikasi terapi DMARD (MTX atau sulfasalazin).

Kontraindikasi adalimumab.

1. Sedang mendapat terapi imunosupresif, TNF blocking agents, atau anakinra (Kineret ${ }^{\circledR}$, Amgen Inc, Thousand Oaks, CA),

2. Tubekulosis atau infeksi aktif lainnya,

3. Individu yang belum mendapat tes tuberkulin untuk mendeteksi tuberkulosis laten,

4. Alergi latex karena semprit adalimumab mengandung latex,

5. Sklerosis multipel atau penyakit neurologik demyelinating lainnya,

6. Gagal jantung koroner moderate to severe,

7. Ibu hamil atau menyusui.

Efek samping penggunaan pada psoriasis sama dengan placebo. Efektifitas dan keamanan jangka panjang pada psorisis masih dalam penelitian, tetapi resiko infeksi, aktivasi TB, lupus-like, dan sindrom multiple sclerosis-like tetap harus diwaspadai, seperti halnya pada penggunaan infliximab dan etanercept (10).

\section{Abatacept (CTLA-4 Ig fusion protein)}

Merupakan gabungan antara domain eksternal CTLA-4 dengan sekuens rantai berat IgG. CTLA-4 merupakan molekul yang diekspresikan pada permukaan sel $\mathrm{T}$ aktif bersamaan dengan ekspresi CD28. Interaksi CD28 dengan B7-1-2 merupakan stimulator kuat bagi aktivasi, proliferasi, produksi sitokin ( IL-2, IFN- $\gamma$, TNF- $\alpha$, dan GM-CSF), dan kelangsungan hidup sel $\mathrm{T}$. Sebaliknya, interaksi antara CTLA-4 dengan B7-1-2, akan menghasilkan sinyal supresi bagi sel $\mathrm{T}$. Bahan biologik ini berfungsi mengikat B7-1-2 (CD80 dan CD86), sehingga aktivasi, proliferasi, produksi sitokin sel $\mathrm{T}$ terhambat. Selain itu, ekspresi molekul CD40, CD54, MHC II sel keratinosit, dan CD40, CD80, CD86, dan MHC II sel APC dihambat. Semua pengaruh tersebut mengakibatkan aktivitas penyakit berkurang. 
Kerja CTLA-4 Ig fusion protein akan lebih baik apabila diberikan bersama dengan antibodi monoklonal anti CD40L. Selain digunakan untuk kasus psoriasis, bahan ini digunakan untuk memperpanjang survival transplantasi organ alogenik (11).

\section{Belatacept (LEA29Y)}

Merupakan varian abatacept, yang dikembangkan karena CTLA4Ig (abatacept) sering memberikan efek yang unpredictable. Untuk itu, dilakukan substitusi 2 asam amino ke dalam domain CTLA4-fusion protein. Belatacept, memiliki binding avidity $10 \times$ lebih besar terhadap CD80 dan CD86 dibandingkan CTLA4lg. Belatacept efektif sebagai profilaksis terhadap rejeksi transplantasi pada model nonhuman. Belatacept, sebagai investigational selective costimulation blocker, tidak lebih inferior daripada siklosporin dalam pencegahan rejeksi akut transplantasi ginjal. Selain itu, Belatacept mempertahankan glomerular filtration rate dan mengurangi kemungkinan terjadi chronic allograft nephropathy (12).

Daclizumab

Humanized monoclonal antibody anti-CD25. Contoh : Zenapax dari Hoffman-La Roche, Inc, Nutley, NJ. Dengan mengikat CD25 pada permukaan sel $\mathrm{T}$ aktif, maka interaksi IL-2 dengan CD25 terhambat, sehingga proliferasi dan diferensiasi sel $\mathrm{T}$ menjadi sel Th1 efektor dan memory terganggu (13).

\section{Basiliximab}

Simulect, Novartis Pharmaceuticals Corporation, Basel, Switzerland. Kerjanya serupa dengan Daclizumab. Efek penghambatan proliferasi dan diferensiasi kedua bahan tersebut akan lebih baik apabila dikombinasi dengan humanized monoclonal antibody anti-IL-12 (13).

\section{ABX-IL-8}

Fully human anti-IL-8 monoclonal antibody. Contoh: Abgenix, Inc, Fremont, Calif. Berfungsi menetralisir IL-8, sehingga menghambat kemotaksis sel PMN kedalam lesi peradangan.

Kerja ABX-IL-8 tidak optimal, karena:

1. penetrasi $A B X-I L-8$ kedalam jaringan radang kecil

2. produksi IL-8 oleh sel keratinosit didalam jaringan radang terus berlanjut.

3. Infltrasi sel PMN dipengaruhi tidak hanya oleh kemokin IL-8, tetapi juga oleh Gro- $\alpha$ yang banyak diekspresikan dalam lesi (14).

\section{Recombinant IL-10}

Penggunaan pada kasus psoriasis dimaksudkan sebagai Immune deviation, atau Cytokine switching, yaitu menekan sekresi sitokin Th1 sehingga terjadi semacam pergeseran atau keseimbangan sitokin Th1/Th2.

Efek Immune deviation akan lebih baik lagi apabila pemberiannya dikombinasi dengan humanized monoclonal antibody anti-IL-12. (15)

\section{Ustekinumab (CNTO 1275)}

Ustekinumab ialah agen biologik baru hasil pengembangan Centocor, Inc. untuk pengobatan psoriasis plakat moderate to severe. Target ustekinumab ialah IL-12 dan IL-23, protein alami yang penting dalam regulasi sistem imun dan berperan pula dalam immune-mediated inflammatory disorders. Interleukin-23 menstimulasi subset sel Th memory yaitu sel Th17 untuk melepaskan IL-17, yang merupakan penghubung antara aktivasi dan inflamasi sel $T$ (menginduksi pelepasan IL-1, IL-6, IL-8 dan TNF-a pada lesi psoriasis).

Agen biologik tersebut telah diterima oleh FDA untuk di reviewed sebagai agen terapi pasien psoriasis (16). Sebuah randomized trial fase 2 menunjukkan ustekinumab sangat efektif dalam pengobatan psoriasis plakat moderate to severe, dan 2 trial fase 3 telah mengkonfirmasi hasil fase 2. Hasil yang diperoleh pada 766 pasien (fase 2) dan 1230 pasien (fase 3 ) dengan psoriasis plakat moderate to severe mendapatkan pasien yang diobati dengan ustekinumab $45 \mathrm{mg}$ atau $90 \mathrm{mg}$ mencapai minimal $75 \%$ perbaikan pada minggu ke 12 , dibandingkan plasebo (67\% dan $66 \%$ versus $3 \%$ ). Ustekinumab diberikan 1 x/bulan s.c. untuk 2 dosis pertama, dan selanjutnya tiap 12 minggu. Responders yang mengikuti seluruh terapi, dapat mempertahankan perbaikan klinis, minimal 76 minggu. Efek samping yang terjadi tidak berbeda dengan placebo (17).

\section{ABT-874}

ABT-874, antibodi monoklonal lain dengan target terhadap IL-12/23 tampak sangat efektif pada pasien psoriasis plakat moderate to severe (randomized trial fase 2) (18).

\section{KESIMPULAN}

Pasien psoriasis moderate to severe, secara tradisional diobati dengan terapi sistemik atau terapi foto, di antaranya siklosporin, MTX, retinoids, ultraviolet $A$ dan psoralen (PUVA), dan ultravilet $B$ (UVB). Pengobatan tersebut sering tidak memenuhi harapan pasien dan dokter karena adanya efek samping signifikan (toksisitas organ, kanker kulit, kurangnya efikasi yang berlangsung lama, dan skedul pemberian obat yang tidak mudah.

Keterbatasan terapi tradisional dan pemahaman yang meningkat mengenai dasar imunologis psoriasis telah menghasilkan penemuan dan penggunaan agen biologik. Agen baru tersebut memberikan keuntungan klinis bagi pasien yang tidak dapat mentolerir atau obat tradisional tersebut kontraindikasi. Hasil clinical trials awal menunjukkan agen biologik memberikan high response rates dan mengurangi collateral organ toxicity dan efek samping yang sering timbul pada terapi imunosupresif sebelumnya. Walaupun agen biologik menunjukkan kelebihan dibandingkan obat imunosupresif terdahulu, 
pemberian agen biologik memerlukan beberapa pertimbangan, di antaranya.

1. Harga agen biologik,

2. Biaya pemeriksaan laboratorium untuk memonitor efek samping,

3. Potensi aktivasi infeksi laten, terutama agen biologik dengan target TNF- $\alpha$ (etanercept, infliximab, adalimumab), dan agen biologik yang mengakibatkan sitotoksis sel $T$ memory (alefacept),
4. Potensi efek yang tidak diinginkan seperti demyelinating diseases,

5. Keamanan pemakaian jangka panjang (efalizumab yang telah disetujui FDA kemudian ditarik dari peredaran karena efek samping fatal),

Terapi biologik merupakan langkah maju dalam terapi psoriasis plakat moderate to severe, namun kemajuan tersebut bukanlah pencapaian akhir karena belum mencapai terapi kausal psoriasis.

\section{DAFTAR KEPUSTAKAAN}

1. Kruger JG. The immunologic basis for the treatment of psoriasis with new biologic agents. Continuing Medical Education. J Am Acad Dermatol 2002;46:1-23.

2. Gordon KB, West DT. Biologic therapy in psoriasis. In: S. Wolverton, ed. Comprehensive Dermatologic Drug Therapy.Philadelphia, PA: WB Saunders Co;2001:928-942

3. Pariser DM. Treating Psoriasis Patients with biologic agents. Improved outcomes with new biologic agents are prompting physicians to intergrate them into therapy for psoriasis patients. MANAGE CARE, 2003.

4. Winhoven SM. and Griffiths CEM. Biologics for Psoriasis. The Dermatology Centre, The University of Manchester, Hope Hospital, Manchester, UK, 2005.

5. Vaishnaw AK, Ticho B. Alefacept is efficacious in a broadspectrum of patients with psoriasis, including those with severe disease. Presented at the $61^{\text {st }}$ Annual Meeting of the American Academy of Dermatology; March21-26, 2003; San Fransisco.

6. Cather JC, Cather JC, and Menter A. Modulating T cell responses for the treatment of psoriasis: a focus on efalizumab. Expert Opin Biol Ther 2003;3(2):361-370

7. Hitt E. Efalizumab withdrawn from US market. Available from: http://www.medscape.com/viewarticle/590862?src=mp\&spon=33\&uac=91557DY. (Cited 2009 April 15).

8. Gottlieb AB, Li S, Evans R, et al. Infliximab in the treatment of psoriasis: Results from the first 10 weeks of the phase II trial. Presented at the $61^{\text {st }}$ Annual Meeting of the American Academy of Dermatology; March 21-26, 2003; San Fransisco.

9. Leonardi C, Gottlieb AB, Zitnik R, et al. Efficacy and safety of ENBREL., (etanercept) in patients with psoriasis: Results of phase III study.Presented at International Investigative Dermatology 2003; April 30May 4, 2003; Miami Beach.

10. Gordon KB, Blum RR, Papp KA, et al. Efficacy and Safety of Adalimumab Treatment in Patients with moderate to severe Psoriasis: A Double-Blind, Randomized Clinical Trial. Psoriasis Forum, Summer 2007;13(1):4-11

11. Emery P, Davis Jr JC, Klareskog L, Westhovens R. Selective Costimulatory Modulators: Addressing Unmet Needs in Rhematoid Arthritis management. Available from: http://www.medscape.com/viewarticle/496108 13. (Cited 2008 December 14)

12. Vincenti F. Costimulation blockade-what will the future bring?. Nephrol Dial Transpl 2007;22(5):1293-1296.

13. Walsh SRA, Shear NH. Psoriasis and the new biologic agents: interrupting a T-AP dance. CMAJ • June 22 , 2004; 170 (13):1933-1941

14. Feldman SR. What's New in Psoriasis Treatment ?. Available from: http://www.medscape.com/viewarticle/412777. (Cited 2008 January 18).

15. Sterry KAW, Volk HD. Interleukin-10 Therapy-Review of a New Approach. Pharmacol Rev 2003;55:241-269

16. Papp KA, et al. Efficacy and safety of ustekinumab, a human interleukin-12/23 monoclonal antibody, in patients with psoriasis: 52-week results from a randomised, double-blind, placebo-controlled trial (PHOENIX 2). The Lancet 2008;371(9625):1675-1684.

17. Schmidt, C. Ustekinumab poised to enter the psoriasis market. Nat Biotechnol 2008; $26: 1317$

18. Kimball, AB, Gordon, KB, Langley, RG, et al. Safety and efficacy of ABT-874, a fully human interleukin $12 / 23$ monoclonal antibody, in the treatment of moderate to severe chronic plaque psoriasis: results of a randomized, placebo-controlled, phase 2 trial. Arch Dermatol 2008; 144:200. 